\section{Specific deletion of focal adhesion kinase suppresses tumor formation and blocks malignant progression}

\author{
Gordon W. McLean, ${ }^{1,8}$ Noboru H. Komiyama, ${ }^{3,4}$ \\ Bryan Serrels, ${ }^{1}$ Hidefumi Asano, ${ }^{4,7}$ \\ Louise Reynolds, ${ }^{5}$ Francesco Conti, ${ }^{5}$ \\ Kairbaan Hodivala-Dilke, ${ }^{5}$ Daniel Metzger, ${ }^{6}$ \\ Pierre Chambon, ${ }^{6}$ Seth G.N. Grant, ${ }^{3,4}$ and \\ Margaret C. Frame ${ }^{1,2}$
}

\begin{abstract}
${ }^{1}$ The Beatson Institute for Cancer Research, Garscube Estate, Bearsden, Glasgow, G61 1BD, United Kingdom; ${ }^{2}$ Institute of Biological and Life Sciences, University of Glasgow, Glasgow G12 8QQ, United Kingdom; ${ }^{3}$ Wellcome Trust Sanger Institute, Cambridgeshire, CB10 1XA, United Kingdom; ${ }^{4}$ Division of Neuroscience, University of Edinburgh, Edinburgh, EH8 9JZ, United Kingdom; ${ }^{5}$ The London Queen Mary's School of Medicine and Dentistry, John Vane Science Centre, London, EC1M 6BQ, United Kingdom; ${ }^{6}$ Institut de Génétique et de Biologie Moléculaire et Cellulaire, CNRS/INSERM/ULP, Collège de France, 67404 Illkirch Cedex, Strasbourg, France
\end{abstract}

We have generated mice with a floxed fak allele under the control of keratin-14-driven Cre fused to a modified estrogen receptor $\left(\mathrm{Cr}_{\mathrm{ERR}} \mathrm{ER}^{\mathrm{T} 2}\right)$. 4-Hydroxy-tamoxifen treatment induced fak deletion in the epidermis, and suppressed chemically induced skin tumor formation. Loss of fak induced once benign tumors had formed inhibited malignant progression. Although fak deletion was associated with reduced migration of keratinocytes in vitro, we found no effect on wound re-epithelialization in vivo. However, increased keratinocyte cell death was observed after fak deletion in vitro and in vivo. Our work provides the first experimental proof implicating FAK in tumorigenesis, and this is associated with enhanced apoptosis.

Supplemental material is available at http://www.genesdev.org.

Received July 1, 2004; revised version accepted October 14, 2004.

Cellular focal adhesions are complex structures consisting of many interacting proteins that provide both physical adhesion to extracellular matrix, usually via transmembrane integrin receptors, and that also transmit survival and/or growth signals into the cell interior. Deregulation of these adhesions may permit cancer cells to migrate and invade into surrounding tissue during the

[Keywords: Focal adhesion kinase; conditional; cancer; keratinocyte; apoptosis]

${ }^{7}$ Present address: Chiba-City Kaihin Hospital, 3-31-1 Isobe, Mihama-Ku, Chiba City, Japan.

${ }^{8}$ Corresponding author.

E-MAIL g.mclean@beatson.gla.ac.uk; FAX 44-141-942-6521.

Article and publication are at http://www.genesdev.org/cgi/doi/10.1101/ gad.316304. development of malignant disease, or to survive and grow under normally inappropriate conditions. One major component of integrin adhesions is focal adhesion kinase (FAK), a nonreceptor tyrosine kinase that is pivotal in many signaling pathways (Ilic et al. 1997). FAK regulates integrin-mediated adhesion and cell migration, and contributes to proliferation and cell survival (Schaller 2001; Hauck et al. 2002). Despite numerous reports that FAK expression correlates with the development of cancer (Owens et al. 1995, 1996; Agochiya et al. 1999; Jones et al. 2000; McLean et al. 2003), there is no direct evidence whether, and if so how, FAK contributes to cancer development.

Using fak heterozygous (+/-) mice, we previously demonstrated that reduced FAK expression had a negative impact on chemically induced papilloma formation (McLean et al. 2001). However, these benign tumors from $\mathrm{fak}^{+/-}$mice elevated expression of FAK to a level that was indistinguishable from papillomas from wildtype $\mathrm{fak}^{+/+}$mice, preventing us from addressing the key question of whether FAK expression is causally involved in malignant progression. Here, we address whether FAK plays a causal role in development of the malignant phenotype in vivo, by generating mice in which we had both spatial and temporal control over fak deletion. Specifically, we used gene targeting in embryonic stem (ES) cells to generate mice that are homozygous for a floxed fak allele, and that also express a 4-hydroxy-tamoxifen (4-OHT)-regulated Cre recombinase (Cre-ER ${ }^{\mathrm{T} 2}$ ) expressed under control of the keratin-14 promoter (K14CreER ${ }^{\mathrm{T} 2}$ / FAK $^{\text {flox/flox }}$. We could delete fak from the epidermis of these mice upon addition of $4-\mathrm{OHT}$, but more importantly from benign papilloma tumors once these had developed. Our results provide the first evidence that FAK modulates the efficiency of benign tumor formation and plays a crucial role in malignant conversion.

\section{Results and Discussion}

To investigate the role of FAK during the formation and development of skin tumors, we used Cre/loxP technology to target the introduction of conditional mutations into the fak gene in mice. As the fak coding exons are spread over $>225 \mathrm{~kb}$, it was not practical to flox the entire fak gene; instead, loxP sites were introduced into the fak gene at positions flanking the exon encoding part of the kinase domain, that is, FAK amino acids 413-444. (The gene-targeting strategy and generation of FAK floxed mice are described in detail in the Supplemental Material.) The targeting vector was designed so that Cremediated recombination also introduced a frameshift mutation in the adjacent exon, precluding production of a functional FAK protein. Screening of Cre-expressing ES cells by immunoblotting confirmed that no FAK protein was detectable (Fig. 1A). Using $\mathrm{N}$-terminal antibodies to FAK, no truncated products were visualized (data not shown). To obtain epidermal-specific fak excision, we

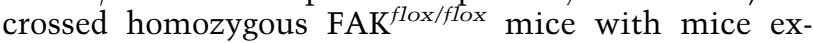
pressing a modified estrogen receptor-Cre fusion protein (CreER ${ }^{\mathrm{T} 2}$ ) (Indra et al. 1999), under the control of the keratin-14 (K14) promoter. This directs 4-OHT-induced excision of floxed fak to epidermal keratinocytes of mouse skin (Indra et al. 1999; Li et al. 2000). The resulting $\mathrm{K} 14 \mathrm{Cre} \mathrm{ER}^{\mathrm{T} 2} / \mathrm{FAK}^{\text {flox/flox }}$ mice were viable and dis- 
played skin-specific suppression of FAK expression following administration of 4-OHT, while other tissues, such as kidney and spleen, remained unaffected (Fig. 1B). Although some FAK was also detected in immunoblots of epidermal extracts from 4-OHT-treated animals (Fig. $1 \mathrm{~B}$, lane 6), this is most likely due to FAK expression in the underlying dermis that contaminates the epidermal preparations, or to the presence of a small number of keratinocytes that had not undergone FAK deletion due to loss of K14 expression through differentiation (Stoler et al. 1988). Immunohistochemistry revealed reduced FAK expression in both the epidermis and hair follicles of $\mathrm{K} 14 \mathrm{Cre} \mathrm{ER}^{\mathrm{T} 2} / \mathrm{FAK}^{\text {flox/flox }}$ mice, when compared with underlying dermis (Fig. 1C). This temporally controlled deletion of fak allowed separation of effects on benign tumor formation from those on malignant conversion.

Skin tumors were induced in 4-OHT-treated and untreated $\mathrm{K} 14$ Cre $\mathrm{ER}^{\mathrm{T} 2} / \mathrm{FAK}^{\text {flox/flox }}$ mice by a two-stage chemical carcinogenesis protocol (Quintanilla et al.
1986; Kemp et al. 1993; Yuspa et al. 1995), as well as in $\mathrm{K} 14$ Cre $\mathrm{ER}^{\mathrm{T} 2}$ and 4-OHT-treated FAK ${ }^{\text {flox/flox }}$ mice to rule out possible effects of Cre expression or 4-OHT treatment, respectively. Treatment with the carcinogen 7,12dimethylbenzanthracene (DMBA) gives rise to activating mutation of the c-Ha-Ras gene (Quintanilla et al. 1986; Pelling et al. 1987), and subsequent treatment for $20 \mathrm{wk}$ with the tumor promoter 12-O-tetradecanoylphorbol-13acetate (TPA) leads to formation of benign papillomas, a proportion of which progress to form invasive squamous cell carcinomas (SCC) (Burns et al. 1978). We observed a marked difference in papilloma formation between 4-OHT-treated and untreated K14Cre $\mathrm{ER}^{\mathrm{T} 2} / \mathrm{FAK}^{\text {flox/flox }}$ mice. Only $50 \%$ of 4 -OHT-treated mice formed papillomas after $12 \mathrm{wk}$, as compared to $100 \%$ of untreated mice (Fig. 1D). More significantly, there was also a substantial reduction in the average number of papillomas formed per 4-OHT-treated K14Cre ER ${ }^{\mathrm{T} 2} / \mathrm{FAK}^{\text {flox/flox }}$ mouse at 22 wk when compared to the untreated control group (Fig. 1E). Additionally, no difference in benign tumor acquisition was observed in either the K14Cre $\mathrm{ER}^{\mathrm{T} 2}$ or the 4-OHT-treated $\mathrm{FAK}^{\text {flox/flox }}$ mice ruling out any possible effects of Cre expression or 4-OHT treatment, respectively (data not shown). This indicates that FAK plays a modulatory role in chemically induced, Ras-dependent papilloma formation, with half of the 4-OHTtreated $\mathrm{K} 14 \mathrm{Cre} \mathrm{ER}^{\mathrm{T} 2} / \mathrm{FAK}^{\text {flox/flox }}$ mice being resistant to DMBA/TPA-induced benign tumor formation. We have reported previously that keratinocytes derived from $\mathrm{fak}^{+/-}$heterozygous mice display impaired signaling to Ras effector pathways (McLean et al. 2001), such as ERK/MAP kinase. Taken with our current findings, the data indicate that FAK is necessary not only for the biochemical effects of Ras in cells in culture, but also for optimal tumor initiating/promoting biological effects of oncogenic Ras in vivo.

Experiments using immortalized $\mathrm{fak}^{-/-}$ mouse embryo fibroblasts have implicated FAK in migration and invasion (Ilic et al. 1995), while FAK expression in tumors correlates with invasive potential (Owens et al. 1995). However, owing to the embryonic lethality of constitutive fak deletion (Ilic et al. 1995), no experiments have been done to test whether FAK has a causal role in the development of malignancy per se. We therefore deleted fak directly from preformed benign papillomas and examined subsequent progression to invasive SCC tumors. K14Cre $\mathrm{ER}^{\mathrm{T} 2} / \mathrm{FAK}^{\text {flox/flox }}$ mice were subjected to DMBA and TPA, and subsequently treated with 4-OHT after the majority of papillomas had formed (at $15 \mathrm{wk}$ as indicated in Fig. 2A). Immunohistochemistry confirmed fak gene excision after 4-OHT treatment, as judged by loss of specific FAK staining in hyperproliferative epidermal regions of papilloma sections (Fig. 2B, right panel). As judged by visual identification and subsequent histological confirmation of SCC, $4.1 \%$ of papillomas 
$\mathbf{A}$
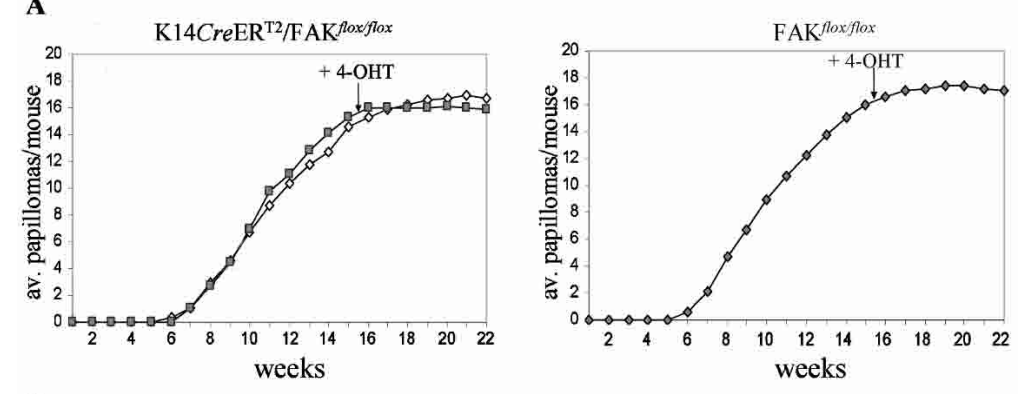

B

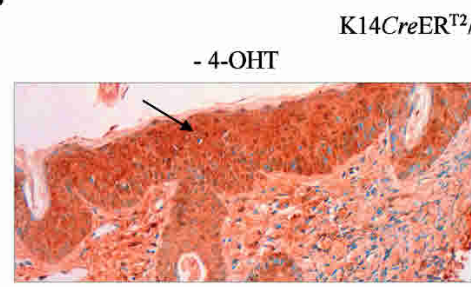

C

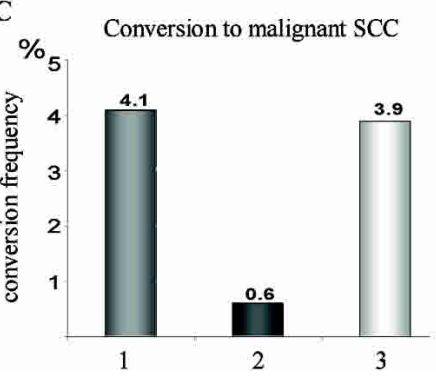

Figure 2. Deletion of fak from papillomas blocks malignant progression to SCC. $(A)$ Mice either K14Cre $\mathrm{ER}^{\mathrm{T} 2} / \mathrm{FAK}^{\text {flox/flox }}$ (left panel) or $\mathrm{FAK}^{\text {flox/flox }}$ (right panel) were treated with vehicle alone or with 4-OHT $(+4-\mathrm{OHT})$ at $15 \mathrm{wk}$ after the majority of papillomas had formed. (B) Immunohistochemical anti-FAK staining of paraffinembedded sections of papillomas from K14Cre $\mathrm{ER}^{\mathrm{T} 2} / \mathrm{FAK}^{\text {flox/flox }}$ mice treated with vehicle alone (left panel) and with 4-OHT (right panel). (C) Papilloma to carcinoma conversion frequency of 4-OHT-treated and untreated $\mathrm{K} 14 C r e \mathrm{ER}^{\mathrm{T} 2} / \mathrm{FAK}^{\text {flox/flox }}$ mice (1 and 2) and 4-OHT-treated FAK ${ }^{\text {flox/flox }}$ mice (3). Conversion frequency is determined by calculating the number of carcinomas recorded per total number of papillomas for each study group. $(D)$ Anti-FAK immunoblot of proteins extracted from SCCs derived from untreated (lanes 1-6) or 4-OHT-treated (lanes 7,8) K14CreER ${ }^{\mathrm{T} 2}$ / FAK $^{\text {flox/flox }}$ mice.

underwent conversion to carcinoma in untreated mice, whereas malignant conversion of papillomas in 4-OHTtreated $\mathrm{K} 14$ Cre $\mathrm{ER}^{\mathrm{T} 2} / \mathrm{FAK}^{\text {flox/flox }}$ mice was reduced to $0.6 \%$ (Fig. 2C). An observed conversion frequency of $3.9 \%$ in 4 -OHT-treated FAK flox/flox $^{\text {mice excluded the }}$ possibility of this observation being linked to administration of $4-\mathrm{OHT}$ (Fig. 2C). The $0.6 \%$ conversion frequency represented two SCCs that developed in 4-OHTtreated $\mathrm{K} 14 \mathrm{Cre} \mathrm{ER}^{\mathrm{T} 2} / \mathrm{FAK}^{\text {flox/flox }}$ mice, and subsequent immunoblotting of lysates prepared from these tumors demonstrated retention of FAK expression at levels in the same range as SCCs developed from untreated $\mathrm{K} 14$ Cre $\mathrm{ER}^{\mathrm{T} 2} / \mathrm{FAK}^{\text {flox } / \text { flox }}$ mice (Fig. 2D, lanes 7,8 ). Therefore, these two SCCs had arisen from papillomas in which the fak gene had not been excised by 4-OHT treatment. Crucially, FAK-deficient SCCs never arose during our experiments, implying that loss of FAK expression from the hyperproliferative epidermal region of papillomas is incompatible with malignant progression.

Deriving keratinocytes from K14Cre $\mathrm{ER}^{\mathrm{T} 2} / \mathrm{FAK}^{\text {flox/flox }}$ mice allowed us to examine the effects of fak deletion in the normal epithelial cells that are the targets for tumorigenesis in the DMBA/TPA skin carcinogenesis model. This provides important advantages over the commonly used $\mathrm{fak}^{-1}$ cells (Ilic et al. 1995), not only because the latter are mesenchymal but also because they are deficient in p53 that might influence their behavior (Ilic et al. 1995). Peripheral FAK staining was visible in untreated keratinocytes, presumably at integrin adhesion sites that represent keratinocyte focal adhesions, whereas 4-OHT treatment caused loss of peripheral FAK staining in the majority of cells (Fig. 3A). The small number of cells that continue to express FAK may be due to suppression of K14 expression that may occur as keratinocytes differentiate (Fig. 3A, right panel, arrow; Stoler et al. 1988). We first carried out wound repair migration assays, and found that 4-OHT-treated K14CreER ${ }^{\mathrm{T} 2} / \mathrm{FAK}^{\text {flox/flox }}$ keratinocytes were unable to repopulate the denuded areas of wounded monolayers when compared to control cultures (Fig. 3B). To address whether this could be explained by defective cell migration, we tracked individual cells using time-lapse microscopy and found that $\mathrm{fak}^{-\mathrm{C}_{-}}$keratinocytes displayed reduced migration rates (by $\sim 50 \%$ ), but they were still visibly motile (Fig. 3C). However, we noticed that there were fewer cells present even in the confluent regions at the wound edges after 48 $\mathrm{h}$ (Fig. 3B, arrows), suggesting that failure to repair the wound in vitro may be associated with detachment and/or cell death. We collected adherent and detached cells following treatment with 4-OHT and determined the proportion of cells with sub-2n DNA content by FACS analysis. We found that loss of FAK was associated with loss of normal cell cycle profiles and a substantial amount of cell death when compared with untreated primary keratinocytes (Fig. 3D,E).

Our data thus provide the first direct experimental evidence that FAK causally contributes to the development of malignancy in vivo, specifically during the benign papilloma to SCC transition. Furthermore, this is associated with a requirement for FAK to maintain a normal rate of cell migration, and survival signaling in keratinocytes in vitro. To determine which, if either, of these effects is likely to be responsible for the observed suppression of tumorigenesis upon FAK deletion, we carried out punch biopsy wound repair assays and analyzed caspase- 3 activation in 4-OHT-treated $\mathrm{K} 14 \mathrm{Cre} \mathrm{ER}^{\mathrm{T} 2} / \mathrm{FAK}^{\text {flox flox }}$ skin to monitor in vivo migration and apoptosis, respectively. $\mathrm{K} 14$ Cre $\mathrm{ER}^{\mathrm{T} 2} / \mathrm{FAK}^{\text {flox/flox }}$ mice (either treated or untreated with 4-OHT) were wounded with $3-\mathrm{mm}$ punch biopsies (Fig. 4A, day 0, upper panels), and subsequent wound closure was monitored. No visible difference in in vivo wound repair was observed-as judged at $7 \mathrm{~d}$ after wounding-when re-epithelialization was essentially complete in both cases (Fig. 4A, day 7, lower panels). Earlier time points at days 1 and 3 did not indicate any lag in re-epithelialization of the wounded skin /data not shown). In contrast, we observed a difference in staining of activated caspase- 3 both in the skin and in papillomas 
A

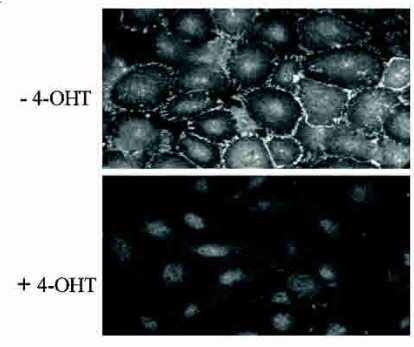

B
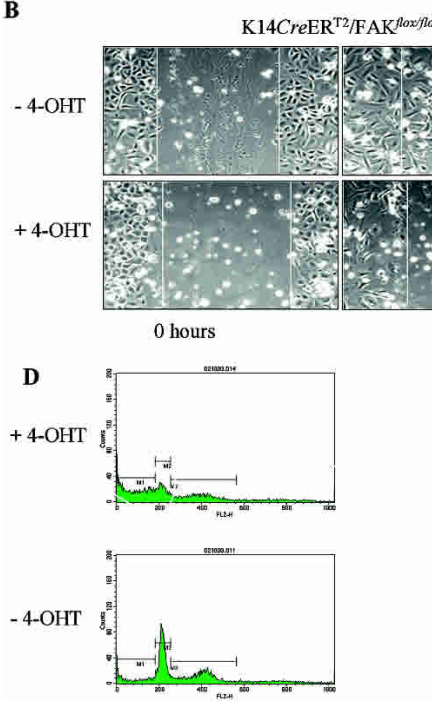

$\mathrm{K}_{14 C r e \mathrm{ER}^{\mathrm{T}} / \mathrm{FAK}}^{\text {flox/lox }}$

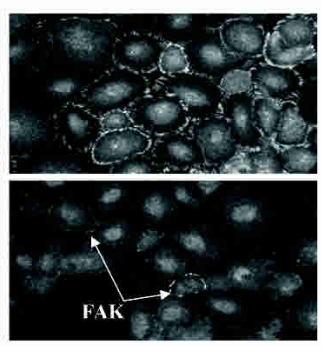

C

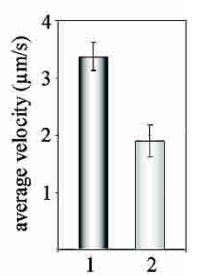

48 hours

$\mathbf{E}$

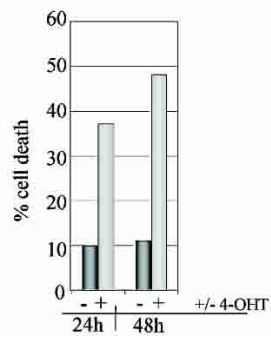

Figure 3. Deletion of FAK from keratinocytes causes reduced migration and increased cell death. $(A)$ Confocal images show anti-FAK staining of peripheral structures in untreated $(-4-\mathrm{OHT})$ or treated (+4-OHT) keratinocytes derived from K14Cre $\mathrm{ER}^{\mathrm{T} 2} / \mathrm{FAK}^{\text {flox/flox }}$ mice. Arrows indicate FAK staining in a minority of treated keratinocytes. Images were taken following $48 \mathrm{~h}$ of $4-\mathrm{OHT}$ treatment. $(B)$ Phasecontrast images show in vitro wound-repair assays of untreated (-4$\mathrm{OHT})$ or treated (+4-OHT) keratinocytes derived from K14Cre $\mathrm{ER}^{\mathrm{T} 2}$ / FAK $^{\text {flox/flox }}$ mice at $0 \mathrm{~h}$ and $48 \mathrm{~h}$ after the wound was made in the monolayer. Arrows indicate areas of the monolayer at the edges of the wound after $48 \mathrm{~h} .(C)$ Migration rates of keratinocytes derived from $\mathrm{FAK}^{\text {flox/flox }}$ mice (1) and K14Cre $\mathrm{ER}^{\mathrm{T} 2} / \mathrm{FAK}^{\text {flox/flox }}$ mice (2), treated with 4-OHT for $48 \mathrm{~h}$, were determined by time-lapse cell tracking and migration rate software analysis expressed as average speed in microns per second. $(D, E)$ Cell death of untreated $(-4-\mathrm{OHT})$ or treated (+4-OHT) keratinocytes derived from K14CreER ${ }^{\mathrm{T} 2}$ FAK $^{\text {flox/flox }}$ mice was judged by the percentage of cells with sub-2n DNA content by FACS analysis; $24 \mathrm{~h}$ and $48 \mathrm{~h}$ refers to the time of sample collection after wounding.

from treated, but not untreated, mice (Fig. 4B). Activated caspase- 3 is accepted as a key marker of apoptotic cells and is now widely considered to be a more reliable indicator of apoptosis in tissue sections than TUNEL staining (Marshman et al. 2001; Duan et al. 2003). In particular, we observed the strongest staining in cells of the hair follicles of 4-OHT-treated mice, where the majority of target cells for DMBA-induced tumorigenesis are thought to reside (Fig. 4B, middle panels; Argyris 1980). Moreover, FAK deletion from preformed benign papillomas caused stronger staining of active caspase-3 (Fig. 4B, lower panels). Thus, it is FAK's role in promoting cell survival that is tightly linked to tumor formation and progression in this mouse.
This, together with the increased expression of FAK during acquisition of malignancy (Owens et al. 1995; McLean et al. 2003), is in keeping with recent observations that FAK can promote invasion in vitro by regulating production of matrix metalloproteinases (Shibata et al. 1998; Hauck et al. 2002). We have now causally implicated FAK as a determinant of malignant behavior in vivo, identifying FAK as an excellent candidate for further study as a potential target to suppress spread of the disease.

\section{Materials and methods}

Animals and gene targeting

Design, construction, and generation of mice containing targeted lox $\mathrm{P}$ sites in the FAK gene are described in detail in the Supplemental Material. Transgenic mice expressing the modified Cre recombinase-estrogen receptor fusion under control of the keratin-14 promoter (K14CreER ${ }^{\mathrm{T} 2}$ ), which targets Cre expression to epidermal keratinocytes, have been described (Li et al. 2000). To facilitate cell-type-specific FAK ablation, FAK $^{\text {flox/flox }}$ mice were then mated to K14Cre $\mathrm{ER}^{\mathrm{T} 2}$ transgenic mice. The resulting offspring carrying $\mathrm{K} 14 \mathrm{Cre} \mathrm{ER}^{\mathrm{T} 2}$ that were either homozygous for the floxed FAK gene (K14Cre $\mathrm{ER}^{\mathrm{T} 2} / \mathrm{FAK}^{\text {flox/flox }}$, carried $\mathrm{K} 14$ Cre $\mathrm{ER}^{\mathrm{T} 2}$ and two copies of the wild-type FAK allele $\left(\mathrm{K} 14 \mathrm{Cre} \mathrm{ER}^{\mathrm{T} 2} / \mathrm{FAK}^{+/+}\right)$or the
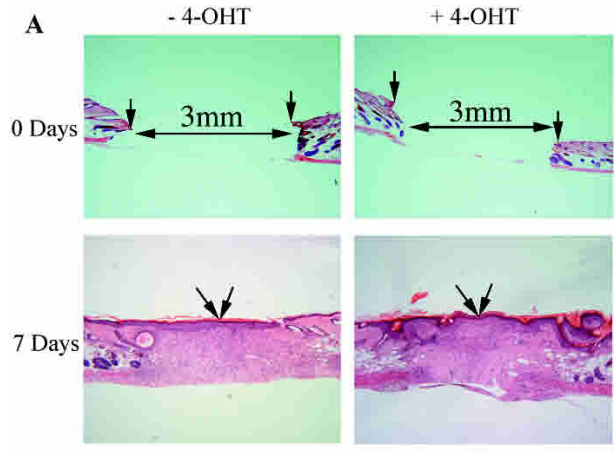

B

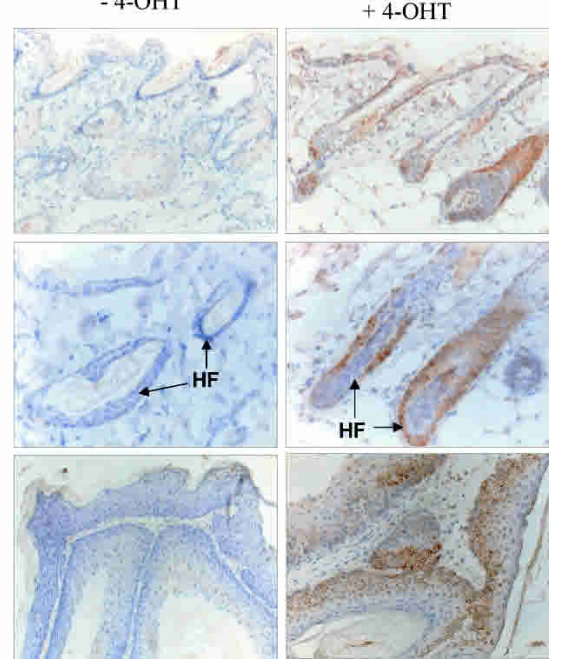

Figure 4. (A) Sections of wounded skin from 4-OHT-treated $1+4$ $\mathrm{OHT}$ ) or untreated (-4-OHT) K14Cre $\mathrm{ER}^{\mathrm{T} 2} / \mathrm{FAK}^{\text {flox/flox }}$ mice were stained with $\mathrm{H} \& \mathrm{E}$ to examine re-epithelialization at day 0 (upper panels) and day 7 (lower panels) post-injury. Arrows indicate the leading edges of migrating epidermis. $(B)$ Immunohistochemical anti-activated caspase-3 staining of sections of either 4-OHT-treated $(+4-\mathrm{OHT})$ or untreated (-4-OHT) skin (upper and middle panels) or papillomas (lower panels) from K14Cre $\mathrm{ER}^{\mathrm{T} 2} / \mathrm{FAK}^{\text {flox/flox }}$ mice. Images taken at either low (upper panels) or high (middle and lower panels) magnification. (HF) Hair follicles. 


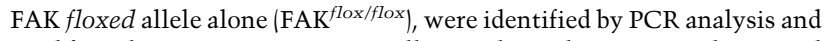
used for subsequent experiments. All animals used were crossed onto and maintained on an FVB genetic background.

\section{PCR genotyping}

Mice that were homozygous for the floxed $f a k$ gene were routinely identified by PCR analysis. Tail DNA was prepared by standard protocols and subjected to PCR analysis using the following primers: FAK30, 5'AGAAAGCTATGGAATAGATGAAG- $3{ }^{\prime}$ and FAK54, 5' $^{\prime}$-GTCTGGTGT TCTGAATAAGGTTGG-3'; and the following FAK-specific amplification protocol: $95^{\circ} \mathrm{C} / 30 \mathrm{sec}(1 \mathrm{cycle}) ; 94^{\circ} \mathrm{C} / 10 \mathrm{sec}+57^{\circ} \mathrm{C} / 30 \mathrm{sec}+68^{\circ} \mathrm{C} / 3$ $\min (10$ cycles $) ; 94^{\circ} \mathrm{C} / 10 \mathrm{sec}+57^{\circ} \mathrm{C} / 30 \mathrm{sec}+68^{\circ} \mathrm{C} / 3 \mathrm{~min}[+20 \mathrm{sec} /$ cycle $]$ (20 cycles); $68^{\circ} \mathrm{C} / 7 \mathrm{~min}(1 \mathrm{cycle})$. Following amplification, PCR DNA products were digested overnight with HindIII and analyzed by agarose gel electrophoresis. Mice that were homozygous for the floxed $f a k$ mutation $\left(\mathrm{FAK}^{\text {flox/flox }}\right.$ exhibited a single major band of $1.9 \mathrm{~kb}$, mice that were heterozygous for floxed FAK $\left(\mathrm{FAK}^{\mathrm{wt} / \text { flox }}\right)$ contained two major bands at 1.9 and $1.4 \mathrm{~kb}$, and wild-type (wt) mice (FAK ${ }^{\mathrm{wt} / \mathrm{wt}}$ ) contained a single band at $1.4 \mathrm{~kb}$ (see Supplemental Material). Mice that additionally contained the $\mathrm{K} 14 C r e \mathrm{Er}^{\mathrm{T} 2}$ transgene were again identified by PCR analysis using the following primers: $5^{\prime}$-ATTTGCCTGCATTACCGGTC-3' and 5'-ATCAACGTTTTCTTTTCGG-3', and standard amplification protocols. Cre-positive mice exhibited a single PCR product of $350 \mathrm{bp}$.

Preparation and administration of 4-OHT

Preparation and administration of 4-OHT was as described (Indra et al. 1999) except that a reduced dose of $200 \mu \mathrm{g}$ in $100 \mu \mathrm{L}$ of sunflower oil was administered. 4-OHT was administered to 8-wk-old female FVB mice as described (Indra et al. 1999), with animals being left for 8-10 d before the initiation of any further experimental procedures. 4-OHT for in vitro experiments was dissolved in ethanol, stored at $-20^{\circ} \mathrm{C}$, and diluted before use to a final working concentration of $10 \mathrm{nM}$.

\section{Chemical carcinogenesis}

Chemical carcinogenesis using DMBA and TPA was performed on individual study groups of 20 female 8 -wk-old animals as previously described (McLean et al. 2001). The number of benign and malignant tumors was recorded weekly for 45 wk after DMBA treatment. Benign tumor numbers did not increase after 24 wk. Upon collection, tumor tissue was either flash frozen in liquid nitrogen or fixed overnight in phosphate-buffered formalin prior to paraffin embedding and histological examination. Tumors were scored as either papillomas or carcinomas by morphological appearance on collection, followed by histological confirmation after $\mathrm{H} \& \mathrm{E}$ staining of paraffin sections. All experiments were carried out in accordance with the United Kingdom Animal Scientific Procedures Act (1986).

Protein analysis

Protein extracts from tissue culture cells or frozen tissue samples were prepared and blotted onto nitrocellulose as previously described (McLean et al. 2001). Membranes were probed with either FAK mAb at $0.5 \mu \mathrm{g} / \mathrm{mL}$ (clone 77; Transduction Laboratories), or anti-tubulin mAb (Calbiochem). Detection was by incubation with horseradish peroxidase-conjugated secondary antibody (New England Biolabs), and visualization was by enhanced chemiluminescence (Amersham Pharmacia Biotech) according to the manufacturer's instructions.

\section{Immunohistochemistry}

Rabbit polyclonal antibodies against either FAK (Sigma) or activated caspase-3 (Cell Signalling) were used to stain Formalin Fixed Paraffin Embedded (FFPE) tissue using a two-step immunohistochemical technique. Two-micron-thick FFPE tissue sections mounted onto Superfrost slides (Menzel-Glazer) were dewaxed in HistoClear solution (National Diagnostics) followed by stepped rehydration via a series of graded alcohols to water. A negative control was compared in parallel to the investigated sections by omitting the primary antibody step. Antibody was diluted in $0.1 \mathrm{~g}$ of bovine serum albumin (BDH), $0.01 \mathrm{~g}$ of Sodium Azide (BDH) in $0.01 \mathrm{M}$ Tris-buffered saline (pH 7.5) and incubated for $2 \mathrm{~h}$ at room temperature, followed by visualization with a Cytomation EnVision kit (DAKO) (as per manufacturers' instructions). All staining was performed using a Sequenza (Thermoshandon) semiautomated staining facility. Resulting sections were analyzed and images were captured digitally using a Zeiss Axioskop 50 microscope and Axiovision software version 3.1 .
Generation of murine keratinocytes

Primary murine keratinocytes were prepared and propagated from dorsal skin sections of 1- to 2-d-old mice as previously described (McLean et al. 2001). Harvested cells were then plated onto collagen-I precoated tissue culture dishes (Becton Dickinson), and maintained in a humid $37^{\circ} \mathrm{C} / 3 \%$ $\mathrm{CO}_{2}$ incubator in keratinocyte growth medium (KGM; Clonetics). For experiments involving fak deletion, keratinocytes were pretreated with either 4-OHT (10 nM) in ethanol or vehicle alone, for $48 \mathrm{~h}$ with one change of medium and drug at $24 \mathrm{~h}$. This concentration of tamoxifen was identified by titration experiments to be a dose that induced loss of FAK without adverse effects on control cultures.

\section{Wound healing assay}

For in vitro wound healing experiments, $\mathrm{K} 14 \mathrm{Cre} \mathrm{Er}^{\mathrm{T} 2} / \mathrm{FAK}^{\text {flox/flox }}$ keratinocytes were grown to confluence in $60-\mathrm{mm}$ collagen-I-coated tissue culture dishes (Becton Dickinson) in KGM. Monolayers were wounded using a micropipette tip, and the cells were rinsed with KGM before visualization using a phase-contrast microscope. Cells were treated with either $10 \mathrm{nM} 4-\mathrm{OHT}$ or vehicle alone for $48 \mathrm{~h}$ before wounding. Wound closure was recorded at 0 and $48 \mathrm{~h}$ after 4-OHT removal.

For in vivo wound healing experiments, $\mathrm{K} 14 \mathrm{Cre} \mathrm{ER}^{\mathrm{T} 2} / \mathrm{FAK}^{\text {flox/flox }}$ mice were injected intraperitoneally with $4-\mathrm{OHT}$ as described. Mice were allowed to recover for $10 \mathrm{~d}$ before wounding. All mice were anesthetized with halothane, and the dorsum was shaved and cleaned with $70 \%$ alcohol. Three-millimeter full-thickness cutaneous punch-biopsy wounds were made maintaining the underlying fascia. The wounded tissue was collected at 0 and $7 \mathrm{~d}$ post-injury, bisected, and either fixed in $10 \%$ formalin at room temperature for $24 \mathrm{~h}$, or in acid alcohol (96\% ethanol/ $1 \%$ acetic acid) at $4^{\circ} \mathrm{C}$ for paraffin embedding, or snap-frozen in OCT (Thermo Lifesciences) and stored at $-80^{\circ} \mathrm{C}$ for cryo-sectioning.

\section{Time-lapse microscopy}

$\mathrm{K} 14 C r e \mathrm{Er}^{\mathrm{T} 2} / \mathrm{FAK}^{\text {flox/flox }}$ keratinocytes were harvested as described and plated onto collagen-I-coated six-well tissue culture dishes (Becton Dickinson). Following 4-OHT or vehicle alone treatment, cells were monitored using time-lapse video microscopy with images captured from each well every 20 min over a 10-h period. Quantification of cell motility was achieved by analysis of captured images using cell tracking software (Kenetic Imaging Ltd).

\section{Confocal immunofluorescence microscopy}

$\mathrm{K} 14 \mathrm{Cre} \mathrm{Er}^{\mathrm{T} 2} / \mathrm{FAK}^{\text {flox/flox }}$ keratinocytes were grown on glass coverslips, fixed at room temperature for $10 \mathrm{~min}$ with $3.7 \%$ formaldehyde/PBS, and permealized with $0.5 \%$ Triton X-100 in PBS and incubated with anti-FAK $\mathrm{mAb}$ (Transduction Laboratories). Antibody detection was via fluorescein isothiocynate-conjugated goat anti-mouse IgG (Jackson), for $45 \mathrm{~min}$ at room temperature. Fluorescence was visualized using a Bio-Rad MRC 600 confocal microscope.

\section{FACS analysis}

$\mathrm{K} 14 \mathrm{Cre} \mathrm{ER}^{\mathrm{T} 2} / \mathrm{FAK}^{\text {flox/flox }}$ keratinocytes were either treated with 4-OHT or vehicle alone, washed $1 \times$ in PBS, and fixed in $70 \%$ ethanol for $3 \mathrm{~h}$ at $4^{\circ} \mathrm{C}$. Fixed cells were pelleted at $1000 \mathrm{rpm}$ for $5 \mathrm{~min}$, washed $1 \times$ in PBS, and resuspended in propidium iodide solution $(1 \mathrm{mg} / \mathrm{mL})$. Labeled cell populations were analyzed by fluorescence activated cell sorting (FACS) analysis using a Becton Dickinson Cellquest FACScan.

\section{Acknowledgments}

We thank Rebecca Porter for advice and John Wyke and Malcolm Hodgins for critical reading and comments. We also thank Colin Nixon for immunohistochemical analysis. This work was supported by Cancer Research UK at the Beatson Institute (G.W.M., B.S., M.C.F.) and by Collège de France, Association pour la Recherche sur le Cancer, and Foundation pour le Recherche Médicale (D.M. and P.C.).

\section{References}

Agochiya, M., Brunton, V.G., Owens, D.W., Parkinson, E.K., Paraskeva, C., Keith, W.N., and Frame, M.C. 1999. Increased dosage and amplification of the focal adhesion kinase gene in human cancer cells. Oncogene 18: 5646-5653. 
Argyris, T.S. 1980. Tumour promotion by abrasion induced epidermal hyperplasia in the skin of mice. J. Invest. Dermatol. 75: 360-366.

Burns, F.J., Vanderlaan, M., Snyder, E., and Albert, R.E. 1978. Induction and progression kinetics of mouse skin papillomas. In Carcinogen esis, mechanisims of tumour promotion and co-carcinogenesis (eds. T.J. Slaga and R.K. Boutwell), pp. 91-96. Raven Press, New York.

Duan, W.R., Garner, D.S., Williams, S.D., Funckes, C.L., Spath, I.S., and Bloome, E.A. 2003. Comparison of immunohistochemistry for activated caspase-3 and cleaved cytokeratin 18 with the TUNEL method for the quantification of apoptosis in histological sections of PC3 subcutaneous xenographs. I. Pathol. 199: 221-228.

Hauck, C.R., Hsia, D.A., and Schlaepfer, D.D. 2002. The focal adhesion kinase-A regulator of cell migration and invasion. IUBMB Life 53: 115-119.

Ilic, D., Furuta, Y., Kanazawa, S., Takeda, N., Sobue, K., Nakatsuji, N., Nomura, S., Fujimoto, J., Okada, M., and Yamamoto, T. 1995. Reduced cell motility and enhanced focal adhesion contact formation in cells from FAK-deficient mice. Nature 377: 539-544.

Ilic, D., Damsky, C.H., and Yamamoto, T. 1997. Focal adhesion kinase: At the crossroads of signal transduction. J. Cell Sci. 110: 401-407.

Indra, A.K., Warot, X., Brocard, J., Bornert, J.M., Xiao, J.H., Chambon, P., and Metzger, D. 1999. Temporally-controlled site-specific mutagenesis in the basal layer of the epidermis: Comparison of the recombinase activity of the tamoxifen-inducible Cre-ER(T) and Cre-ER(T2) recombinases. Nucleic Acids Res. 27: 4324-4327.

Jones, R.J., Brunton, V.G., and Frame, M.C. 2000. Adhesion-linked kinases in cancer; emphasis on src, focal adhesion kinase and PI 3-kinase. Eur. J. Cancer 36: 1595-1606.

Kemp, C.J., Donehower, L.A., Bradley, A., and Balmain, A. 1993. Reduction of p53 gene dosage does not increase initiation or promotion but enhances malignant progression of chemically induced skin tumors. Cell 74: 813-822.

Li, M., Indra, A.K., Warot, X., Brocard, J., Messaddeq, N., Kato, S., Metzger, D., and Chambon, P. 2000. Skin abnormalities generated by temporally controlled $\mathrm{RXR} \alpha$ mutations in mouse epidermis. Nature 407: 633-636.

Marshman, E., Ottewell, P.D., Potten, C.S., and Watson, A.J. 2001. Caspase activation during spontaneous and radiation-induced apoptosis in the murine intestine. J. Pathol. 195: 285-292.

McLean, G.W., Brown, K., Arbuckle, M.I., Wyke, A.W., Pikkarainen, T., Ruoslahti, E., and Frame, M.C. 2001. Decreased focal adhesion kinase suppresses papilloma formation during experimental mouse skin carcinogenesis. Cancer Res. 61: 8385-8389.

McLean, G.W., Avizienyte, E., and Frame, M.C. 2003. Focal adhesion kinase as a potential target in oncology. Expert Opin. Pharmacother. 4: 227-234.

Owens, L.V., Xu, L., Craven, R.J., Dent, G.A., Weiner, T.M., Kornberg, L., Liu, E.T., and Cance, W.G. 1995. Overexpression of the focal adhesion kinase $\left(\mathrm{p} 125^{\mathrm{FAK}}\right)$ in invasive human tumors. Cancer Res. 55: 2752-2755.

Owens, L.V., Xu, L., Dent, G.A., Yang, X., Sturge, G.C., Craven, R.J., and Cance, W.G. 1996. Focal adhesion kinase as a marker of invasive potential in differentiated human thyroid cancer. Ann. Surg. Oncol. 3: $100-105$.

Pelling, J.C., Fischer, S.M., Neades, R., Strawhecker, J., and Schweickert, L. 1987. Elevated expression and point mutation of the Ha-ras protooncogene in mouse skin tumors promoted by benzoyl peroxide and other promoting agents. Carcinogenesis 8: 1481-1484.

Quintanilla, M., Brown, K., Ramsden, M., and Balmain, A. 1986. Carcinogen-specific mutation and amplification of Ha-ras during mouse skin carcinogenesis. Nature 322: 78-80.

Schaller, M.D. 2001. Biochemical signals and biological responses elicited by the focal adhesion kinase. Biochim. Biophys. Acta 1540: 1-21.

Shibata, K., Kikkawa, F., Nawa, A., Thant, A.A., Naruse, K., Mizutani, S., and Hamaguchi, M. 1998. Both focal adhesion kinase and c-Ras are required for the enhanced matrix metalloproteinase 9 secretion by fibronectin in ovarian cancer cells. Cancer Res. 58: 900-903.

Stoler, A., Kopan, R., Duvic, M., and Fuchs, E. 1988. Use of monospecific antisera and cRNA probes to localize the major changes in keratin expression during normal and abnormal epidermal differentiation. J. Cell Biol. 107: 427-446.
Yuspa, S.H., Hennings, H., Dlugosz, A., Tennenbaum, T., and Glick, A. 1995. The role of growth factors in mouse skin tumor promotion and premalignant progression. Prog. Clin. Biol. Res. 391: 39-48. 


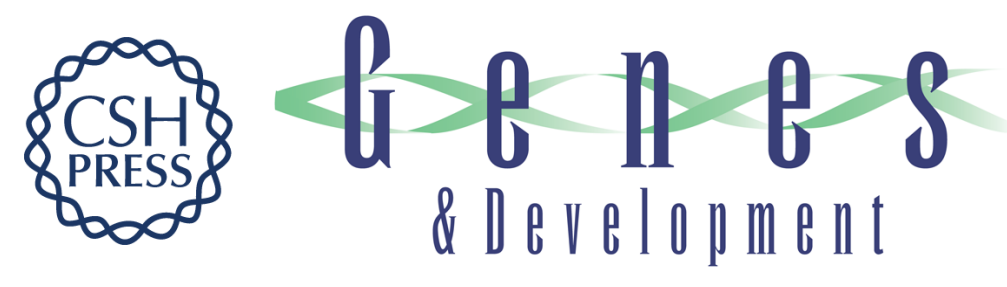

\section{Specific deletion of focal adhesion kinase suppresses tumor formation and blocks malignant progression}

Gordon W. McLean, Noboru H. Komiyama, Bryan Serrels, et al.

Genes Dev. 2004, 18:

Access the most recent version at doi:10.1101/gad.316304

Supplemental
Material http://genesdev.cshlp.org/content/suppl/2005/01/07/18.24.2998.DC1

References This article cites 20 articles, 5 of which can be accessed free at:

http://genesdev.cshlp.org/content/18/24/2998.full.html\#ref-list-1

License

Email Alerting Receive free email alerts when new articles cite this article - sign up in the box at the top

Service right corner of the article or click here.

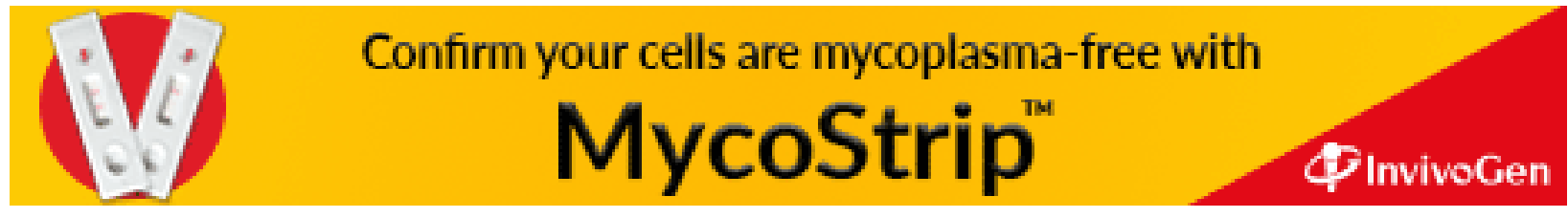

